\title{
NATION BRANDS AND TOURIST DESTINATIONS - AN EXPLORATORY ANALYSIS OF ROMANIA IN THE CONTEXT OF CENTRAL AND EASTERN EUROPE MARKETS
}

\author{
Professor PhD Virgil Balaure, Romanian-American University Bucharest \\ Associate Professor PhD Călin Vegheş, Academy of Economic Studies Bucharest
}

\begin{abstract}
Creation, development and employment of brands have recently become activities that tend to expand beyond the sphere of marketing communication of the organization and generating significant effects over the results of marketing activities and overall performances of the organizations.

Paper intends to approach in an exploratory manner the way brands contribute to the image development of the tourist destinations based on a comparative analysis of the performances generated by the nation brands used to promote different national tourist destinations in Romania and other Central and Eastern Europe countries.
\end{abstract}

Keywords: nation brands, tourist destinations, communication

JEL Codes: M31

\section{Introduction}

Brands represent one of the areas of implementation of marketing communication of the organization whose importance has significantly grown in the recent years. If their value has initially been seen especially in connection to the trade name of organizations' products and services and primarily in the legal context, brands and their employment are nowadays considered key factors to the success of the organization in the market. Thus, the creation, development and employment of brands have become activities that have exceeded the area of marketing communication and whose effects are visible in the results of the marketing and overall activities of the organization. Brands tend to be used in an increasingly diversified context more and more separated from the field of consumer goods which it has provided the support for their current development (Jevons, 2005).

American Marketing Association defines (Kotler, 1997) as a brand name, a term, a sign, a symbol or a drawing or a combination of these elements intended to help in the identification of the goods or services of a seller or group of sellers and to differentiate them from their competitors. Hankinson (2005) considers this type of definition as one of three ways commonly used in the literature to approach the content of the brand adding to this images and identity expressing the significance of the brand or related associations or elements present in the minds of consumers providing the foundation for the brand image formation. From the perspective of marketing, brand utility is associated especially to its capacity to differentiate products and/or services of an organization from those of the competitors and to create a more favorable positioning at the level of the market segments of the organization. Tourism organizations use also the brands as tools of marketing communication aiming to achieve both objectives of communication (in terms of their awareness and, more important, consumer attitude towards them and the offer of the products and services proposed) and objectives related to the sales of the products and services promoted in the market. 


\section{Elements of brand policy}

The set of decisions concerning the building, development and employment of a brand or a portfolio of brands for the products and/or services of a tourist organization describes the content of the brand policy (Balaure, Catoiu and Veghes, 2005). The success of this process depends decisively on its approach in a strategic manner: if is to be considered that brands express the core values of an organization, then the brand policy align the long-term oriented strategies with the current business performances of the organization (Simões and Dibble , 2001). The main decisionmaking areas specific for this process refer to:

- assessment of the opportunity to create a brand or a brands portfolio: for larger or rather smaller tourist organization, present in the markets with different sizes and structures, and providing more or less diversified products and/or services, the existence of a brand under which these will be promoted and sold is a prerequisite and, in some markets, even a requirement for the success of their presence; brands enable organizations to create identity for the products and services offered to the market and to make them more visible to the consumers; by aggregating the improved levels of awareness and attitude, tourist organization may determine significant improvements in terms of its overall or specific products and services images, a more favorable image representing a condition for generating better sales;

- providing support for the future brand development is an extremely sensitive decisionmaking area for launching in the market and constantly growing of the brand: the main problem to be solved refers to the financial resources necessary to support the brand; as investments made by the tourist organizations to support their brands development are consistent, portfolio of brands being among the most expensive tools of marketing communication, the brand development can be done be the tourist service or product provider, the distributor of tourist products and services or by an organization licensed to use the brand;

- names selection for products or services of the tourist organization represents a very important decision-making area considering the perceptions and meanings they will generate among the consumers as well the effects created in terms of the image and sales. From the perspective of the brands significance, tourist organization may consider (Kotler, 1997) characteristics of the product (service) offered, benefits provided by the promoted product (service), values associated with the brand, concepts associated with the brand, brand personality, consumer or user of the brand; tourist organization should choose between building a full brands (collecting and expressing all the six dimensions) or superficial brands (collecting and expressing only some of these dimensions); as regarding the effects generated in terms of the image and sales, selection of a brand name should take into consideration some qualitative characteristics (Popescu, Serbanica, Balaure, 1994) such as the power of evocation, personality, distinction, homogeneity, perceptibility, capacity to be memorized, awareness or capacity to create associations;

- definition and implementation of the brand strategy: tourist organization can choose between four options available in relation to the brand name but also to the position the product or service tour within its offer, respectively strategies of product line extension, brand extension (with the specific sub-options of source-brand strategy or warranty-brand strategy), multiple branding (with the specific sub-options of product-brand strategy, linebrand strategy, range-brand strategy or umbrella-brand strategy) and, last but not least, new brands development strategy;

- adoption of the decision concerning brand repositioning may become appropriate when tourist organizations intends to change the way consumers perceive its products or services as a result of recent less significant contribution of the brand in reaching the communication, 
marketing and sales objectives, or simply as a result of brand damage; repositioning involves the identification of specific criteria (characteristics associated with the technical, financial, commercial and marketing of the brand - in fact of the product, service or destination represented), measurement of the brands performances in connection with these criteria and to the competing brands in the market, identifying of the current position held as well as of the new position to be achieved and recommendation of specific solutions. Implementation of repositioning decision may be done only after a careful assessment of the financial dimensions, respectively of the related costs and revenues. Even if repositioning is seen in the context of the brand policy as a way of improving or developing the image of the tourist organization, it is necessary to assess the investments required for its support in correlation with the anticipated effects in terms of the image and sales and to estimate the time horizon of achieving the specific objectives.

\section{Branding and tourist destinations}

If creation, development and employment of brands are relatively easy to understand for the tourist products and services, in the case of the tourist destinations such activities tend to be more complex (Pike, 2005). Thus, developing a brand for a tourist destination becomes more difficult as a result of the multidimensional nature of the destination itself, the different interests of the stakeholders present in the tourist market, the differences between the theory and specific decisionmaking process involved, on the one hand, respectively the consensus of the involved community, on the other hand, a concrete way of measuring the loyalty to the brand and, last but not least, the problems associated with the financial support of the brand.

\section{Case study: nation brands, tourist destinations and performances in the Central and Eastern Europe markets}

One of the most sensitive topics on the development of brands in the tourism industry is the creation and promotion of nation brands. The importance of this issue has increased with the higher attention given by the organizations involved, not only to the promotion of products and services but also of the tourist destinations. One of the explanations which tend to be increasingly important for the tourism development in the market is the perception that potential tourists associate with a certain destination: more favorable the perception is, higher will be the number of international tourists visiting a tourist destination.

Starting this point, building a nation brand and, in fact, of more and more favorable image of the country is essential. This is based on the answers of questions such as:

- what are the main values associated to the tourist destination?

- what are the values that consumers of tourist products and services seek?

- what are the values that will allow the creation of a distinctive and own image of the tourist destination, able to increase its attractiveness among the potential consumers?

- what will be the content of the message about the tourist destination to be delivered to the consumers?

Creation, development and employment of the nation brands are at the beginning even at the international level. One of the first attempts to define and evaluate the nation brands was completed at the end of May 2005, when Simon Anholt has released the first international ranking of the nation brands, based on a comparative analysis done using the tools of the research company Global Market Insite Inc. at a level of 11 countries in relationship to a set of items relating to products and services, competence and fairness in governance, human capital development, perception of culture, tourism development and business investments.

More recently, the cooperation between Simon Anholt and the marketing research company 
GfK Roper led to the construction of the Nation Brands Anholt-GfK Roper based on a significantly more complex methodology considering as reference dimensions exports, capacity of government, culture and cultural heritage, quality of population, tourism, investment and immigration for 50 countries on all continents of the world.

Concern to build a nation brand for Romania has recently become more important, the specific events occurred (visit of the former US president Bill Clinton, creation of specialized structures to the Presidency, Government and Foreign Ministry, initiation of the public debates on the subject - including the creation of the website www.brandingromania.ro) being conclusive evidences in this respect. Although apparently very recent, these concerns have roots deep enough (Gubernat, 2005): one of the first attempts dates back from 1928 when the government of Iuliu Maniu, through collaboration with the Rockefeller Foundation, has appealed to the most important public relations specialist of the moment - Ivy Lee, asking him to build the country brand of Romania. Unfortunately, the group of experts led by Lee was unable to identify enough arguments to win the confidence of US citizens in the political and economic stability of Romania. Promoting the "national heritage" has continued in the interbellum period through the Romania's participation in international exhibitions held in Gand (1913), Barcelona (1929), Brussels (1935) and Paris (1937 and 1939), aiming mainly to present the image of the past of the Romanian people, country's wealth and the intellectual activities in Romania.

To assess the impact that nation brands can generate over the development of tourism and hospitality industry, were considered data of the World Tourism Organization, for 2006, on the several tourist destinations in the Central and Eastern Europe presented according to the number of tourists attracted international and the amount of revenue generated by foreign tourists attracted. These were correlated with the score obtained by destinations considered the evaluation in the Anholt GMI Nation Brand Index. Specific values of these indicators are presented below.

Table 1

Central and Eastern Europe tourist destinations performances in 2006

\begin{tabular}{|l|c|c|c|}
\hline \multicolumn{1}{|c|}{ Countries } & $\begin{array}{c}\text { International Tourist } \\
\text { Arrivals }\end{array}$ & $\begin{array}{c}\text { International Tourist } \\
\text { Receipts }\end{array}$ & $\begin{array}{c}\text { Anholt GMI Nation } \\
\text { Brand Index 2008 }\end{array}$ \\
\hline Bulgaria & 5158 & 2587 & --- \\
\hline Czech Republic & 6435 & 5007 & 52.5 \\
\hline Estonia & 1940 & --- & 47.6 \\
\hline Hungary & 9259 & 5408 & 52.8 \\
\hline Latvia & 1535 & 498 & --- \\
\hline Lithuania & 2180 & 1038 & 48.0 \\
\hline Poland & 15670 & 7239 & 52.7 \\
\hline Romania & 1380 & 1658 & 48.9 \\
\hline Russian Federation & 20199 & 7628 & --- \\
\hline Slovakia & 1612 & 1512 & --- \\
\hline
\end{tabular}

Notes: number of the international tourist arrivals is expressed in thousands; volume of international tourist receipts is expressed in million US Dollars; --- - unavailable data; sources: World Tourism Organization and Anholt Nation Brands Index.

Measurement of correlations between the three reference variables has been done using the Pearson correlation coefficient and has considered the associations between nation brands and the number of foreign tourists attracted by the tourist destinations, respectively the volume of revenues generated by foreign tourists attracted. Measurements have been limited by the available data. Results of the assessment were the following:

- in the case of the correlation between the specific score of the nation brands and the number of foreign tourists attracted, measurement has been conducted considering the data for 
Czech Republic, Estonia, Hungary, Lithuania, Poland and Romania and the Pearson correlation coefficient determined was equal to 0.83 ; this suggests the existence of a direct and strong relationship between the overall quality of the nation brand and the number of foreign tourists attracted: it can be assumed, that, in the case of the destinations from Central and Eastern Europe, a better nation brand means a higher number of foreign tourists;

- in the case of the correlation between the specific score of the nation brands and the volume of the receipts generated by the foreign tourists attracted, measurement has been conducted considering the data for Czech Republic, Hungary, Lithuania, Poland and Romania and the Pearson correlation coefficient determined was equal to 0.95; this suggests the existence of a direct and very strong relationship between the overall quality of the nation brand and the amount of money the foreign tourists attracted can generate for the tourism and hospitality industry: it can be assumed, that, for the destinations from Central and Eastern Europe, a better nation brand means a higher volume of international receipts;

- finally, the correlation between the number of foreign tourists attracted and volume of the receipts generated by these, measurement has been conducted considering data for Bulgaria, Czech Republic, Hungary, Lithuania, Poland, Romania, Russian Federation and Slovakia and the Pearson correlation coefficient determined was equal to 0.95 ; this suggests existence of a direct and very strong relationship between the number of foreign tourists and the volume of receipts generated.

\section{Limits of the research}

It is difficult to assess that the results obtained above can express to a significant extent the importance that has a nation brand and its effects on the performances of a country seen as a tourist destination. Case study presented must be seen, on the one hand, as an exploratory approach, which aims to contribute at the opening of a discussion on the impact generated by the creation and employment of a nation brand over the development of the tourism and hospitality industry and, and on the other hand, as a model, that extended both quantitatively and qualitatively, can produce consistent results to provide credible answers to the questions concerning the design and employment of a nation brand in terms of the effects generated.

Consideration of all the available data regarding all tourist destinations, increase in the number of indicators to be used beyond the duo number of foreign tourists attracted - the amount of revenue generated, measurement of more complex correlation between the expanded set of reference indicators and nation brands index and, last but not least, modeling the relationships between all these factors represent directions of further action in this research approach.

\section{Conclusions}

In its development, marketing has offered on many occasions, significant opportunities for developing concepts, tools and methods seen as a revolutionary means of developing its conceptual content or as miraculous solutions for the development or recovery of markets, industries or companies. Recently, employment of brands and, particularly, the concept of nation branding have been undoubtedly viewed as solutions for building and promoting of a successful tourist destination. The results of this case study points out that it is not sufficient to use concepts and to promote them aggressively in order to produce significant effects on the tourism and hospitality industry. It is quite obvious that a tourist destination represented through a nation brand favorably perceived worldwide will produce better performances in terms of marketing and revenues but only the nation brand will not succeed to solve the problems of the whole tourism industry or to improve consistently its performances. 


\section{References}

1. Balaure, V., Cătoiu, I., Vegheș, C., 2005, Marketing turistic, Uranus, București

2. Ejarque, J., 2005, Destinos turísticos de éxito. Diseño, creación, gestión y marketing, Ediciones Piramide, Madrid

3. Gubernat, R., 2005, Cum să ne vindem țara!, ApropoTV, Mai, p.48-49

4. Hankinson, G., 2005, Destination brand images: a business tourism perspective, Journal of Services Marketing, Vol. 19, No. 1, p.24-32

5. Jevons, C., 2005, Names, brands, branding: beyond the signs, symbols, products and services, Journal of Product \& Brand, Vol. 14, No. 2, p.117-118

6. Kotler, Ph., 1997, Managementul marketingului: analiză, planificare, implementare, control, Teora, Bucureşti

7. Pike, S., 2005, Tourism destination branding complexity, Journal of Product \& Brand Management, Vol. 14, No. 4, p.258-259

8. Popescu, I. C., Şerbănică, D., Balaure, V., 1994, Tehnici promoționale, Metropol, Bucureşti

9. Simões, C., Dibb, S., 2001, Rethinking the brand concept: new brand orientation, Corporate Communication: An International Journal, Vol. 6, No. 4, p. 217-224

10. *** - The Anholt Nations Brand Index. Special Report Q1 2007, www.simonanholt.com, 2007

11. *** - The Anholt-Gfk Roper Nations Brand Index, www.gfkamerica.com, 2008

12. *** - UNWTO World Tourism Barometer, Vol. 5, No. 1, ianuarie 2007, www.unwto.org 